\title{
The Effect of XBRL Adoption on the Investors' Trading Behavior in Indonesia Stock Exchange
}

\author{
Linda Arisanty Razak ${ }^{1}$, Grace T. Pontoh ${ }^{2}$, Haliah $^{3}$ and Muh. Yamin ${ }^{4}$ \\ ${ }^{1}$ University of Muhammadiyah Makassar, Indonesia \\ ${ }^{2}$ University of Hasanuddin, Indonesia \\ ${ }^{3}$ University of Hasanuddin, Indonesia \\ ${ }^{4}$ STAIN Bone, Indonesia
}

\begin{abstract}
This research aimed to examine the effect of XBRL (Extensible Business Reporting Language) adoption on investors' trading behavior in Indonesia Stock Exchange which was reflected in the frequency of trading on Indonesia Stock Exchange. By using a number of 34 banking issuers taken randomly from a number of 81 banking issuers listed in the Indonesia Stock Exchange in 2014 and 2016, and using one way ANOVA analysis method, for t-test, to see the effect of pre and post XBRL adoption on trading shares frequencies, and also added control variables ROA, SIZE and dividend ratios to the effect of pre XBRL adoption. The results revealed that when post XBRL adoption, the stock trading frequency and control Variable ROA (Return on Assets) did not have any significant changes during the implementation of XBRL, this was due to the sample of financial report data taken from post XBRL, i.e., the 2016 financial data, while the implementation of XBRL only started in 2015, so the implementation of XBRL had not an effective effect on investors, but the other control variable, i.e., SIZE had significant changes during the post XBRL adoption, this implies the effectiveness of XBRL adoption, the increase in the investor's turnover ratio in small companies is more pronounced and economically significant than the large companies. Small companies respond to the existence of XBRL, the response occurs because there is an additional convenience obtained to get more transparent and relevant information to the expected investment decision making. The DEVIDEN as control variable had any significant change during the post XBRL adoption, this indicates that the investors' response to XBRL will increase the frequency of their trading and affect the possibility of obtaining greater dividends.

Keywords: XBRL (Extensible Business Reporting Language) adoption, Frequency of trading, Indonesia Stock Exchange
\end{abstract}

\section{Introduction}

The capital market industry has been growth over time. This can be seen from the increase in the number of companies listed in the Indonesia Stock Exchange which is further called BEI, increasing the dynamics and complexity of corporate actions, as well as increasing types of reporting and information disclosure that are received (BEI, 2014). These developments have led to an increase and complexity in the users of financial information in analyzing companies. Information users, both individual and institutional, need information that can be processed quickly and efficiently. Companies listed in BEI provide financial information to stakeholders in various financial report formats that can be accessed through the website of related companies and BEI website.

The need for financial information for diverse users, especially those related to the financial reporting format, requires companies to present more financial reports from one format (Januaryanto and Oswari, 2015). It is this condition that demands a system of accounting information with a uniform and acceptable financial reporting format by various countries. Then, the need for uniformity is responded by forming a format for reporting systems that are Extensible Business Reporting Language (XBRL) which subsequently referred to as XBRL.

Some research results indicate that investors can easily access financial information after they adopted XBRL; thereby it mitigates information metrics between managers and investors, and increases 
information transparency (Efendi et al., 2014 and Yoon et al., 2011). This study extends previous studies by investigating whether the adoption of XBRL affects trading behavior towards investors.

XBRL is a new technology that facilitates direct searching and simultaneous presentation of related financial reports and footnote information (Hodge and Maines, 2004). XBRL provides identification tags for business information to clarify the information identification and comparison with other companies. The American Institute of CPAs (AICPA) places XBRL as one of the top ten technologies for professional accountants and audits (Peng and Chang, 2010). XBRL is believed to be able to improve the accuracy, reliability, and efficiency of electronic communications of financial business data.

Several studies have proven the benefits of implementing XBRL. Hao et al (2014) proved that the implementing of voluntary XBRL in the United States negatively affected the cost of equity capital. Yoon et al (2011) have proven the effect of XBRL adoption mandatory on information asymmetry in Korea. The results of the study showed a negative relationship between XBRL adoption and information asymmetry. Alles and Piechocki (2012) found that XBRL has the potential to improve governance.

The XBRL implementation provides solutions to problems in the old financial reporting system such as manual data validation, as well as conversion and extracting large amounts of data. XBRL allows users of financial information to analyze data more easily. Through data interoperability capability, XBRL makes it easy for users to compare and analyze information reporting for several business companies.

This study shows two important aspects of XBRL namely (1) XBRL is a global standard language used to submit company financial reports, and (2) XBRL facilitates access to financial information and improves efficiency information. In general, investors are limited to obtain and analyze information about the company. In general, investors are limited to obtaining and analyzing information about the company. So, if XBRL allows investors to easily access financial information because of enhanced information search capabilities, someone can expect that trading investor behavior is clearer than before. Therefore, the main hypothesis in this study is the frequency of trade ratios after XBRL adoption will increase compared to before the implementation of XBRL adoption. The implementation of XBRL in Indonesia was began in 2015; Indonesia began to develop preparations for the implementation of XBRL since 2012 and in 2014 Indonesia made the taxonomy of XBRL published on April 30, 2014. The taxonomy was prepared with reference to the Financial Accounting Standards $(S A K)$, IFRS (International Financial Reporting Standard) Financial Accounting Standards, and the provisions of the Financial Services Authority $(O J K)$. More specifically, XBRL has opened a new research domain in the field of financial accounting and finance, but few researches have examined how XBRL affects the share. The firm size, and trading frequency are the variables that most often appear as factors that affect XBRL.

The entity banking population listed on BEI in 2018 is 81 issuers. In this study, by using a sample of 34 listed companies using a random sample of banking entities on the Indonesia Stock Exchange in 2014 (pre XBRL) and 2016 (post XBRL), researchers examined whether there are differences of the trading frequency ratio level of investment investors in pre- and post-XBRL adoption.

Extensible Business Reporting Language. Information technology practitioners are certainly familiar with the term of eXtensible Markup Language (XML). This markup language has a very important role in changing the internet's features today. XML has become a standard in exchanging data between different systems or platforms. XML is also as one of the key technologies that supports the realization of semantic webs according to Dykes and Title (2005).

The semantic web bridges communication between humans and machines. In the semantic web era, what is displayed on the web can also be read by computer machines (Pollock, 2010). What is the relationship between XML and XBRL? XBRL is an XML language that is created specifically for business purposes. XBRL was introduced by Charles Hoffman in 1998. The basic idea of developing XBRL was to overcome the constraints of interoperability between platforms and speed in the 
distribution and duplication of financial information for the analysis and evaluation purposes (Hoffman: 2006).

XBRL can be interpreted as a markup language that is used to help business activities so that it can efficiently bridge the various obstacles that occur between systems (Hoffman and Watson 2010). The use of XBRL in financial reports makes it easy to compile the large amounts of data, reduce calculations that can pose a large risk of errors, improve the quality and accuracy of information and submission of more timely reports. This open source licensed XBRL language has a similar structure with XML Language. However, XBRL has a better function compared to XML. XBRL is able to accommodate the needs of semantic financial reporting which involves multiple linkages between one element and other elements in multiple relationships. XBRL also has extensibility features that are far better than XML (Farewel, 2010).

Efficient market theory. A market is stated to be efficient if no one, both individual investors and institutional investors, will be able to obtain abnormal returns, after adjusting for risk, using existing trading strategies. This means that the price, volume and share frequency formed on the market reflect the existing information. Fama (1970) divides the capital market efficiency model into three forms based on the information used in decision making:

a) Weak Form. Efficient capital markets in the weak form state that securities prices reflect all information contained in past securities prices. In this condition, no investor can obtain profit levels above normal by using guidelines based on the past price information.

b) Strong Half Form. The efficiency of the capital market in the form of a half strong states that securities prices not only reflect past prices, but also all information published, such as earnings announcements, dividends, mergers, changes in the accounting system and so on. In this condition, no one investor can obtain on the top of normal profit levels by utilizing published sources of information.

c) Strong Form. In the capital market efficiency in a strong form, the price of securities not only reflects all information published but also unpublished information. Investors can obtain the top of normal profit levels by looking at the signals from other investors who have information.

Fama (1970) argues that "In an efficient market, the price will 'fully reflect' the available information and as an implication, the price will respond immediately without any bias towards new information." (2) Beaver (1989) argues that "Market efficiency as the relationship between the prices of stock securities with the availability of information."

The efficient market concept is closely related to the availability of information. The market is stated to be efficient if the value of securities every time reflects all available information, which affects in the price of a security at the level of balance. The balance price of securities affects no opportunity for investors to get an abnormal return from the difference of share securities price. With the existence of XBRL, all information can be available in the market, the market is responded by using information fully and quickly, so that the price of securities changes accordingly reflecting that information to achieve a new balance.

Hypothesis Development. XBRL can really play an important role in achieving the democratization market because it facilitates the continuous flow of information according to Debrecency (2011). The introduction of XBRL has the potential to increase the usefulness of financial data and improve the quality of financial reporting information (Efendi, 2014). XBRL can also improve the financial disclosure environment in the stock market by providing high-quality information to relevant investors. XBRL can also improve the financial disclosure environment on the stock market by providing high quality information to relevant investors.

The implementation of XBRL in Indonesia was began in 2015, Indonesia began to develop preparations for the implementation of XBRL since 2012 and in 2014 Indonesia made the XBRL's taxonomy published on April 30, 2014. The taxonomy was prepared with reference to the Financial Accounting Standards $(S A K)$, IFRS (International Financial Reporting Standard) Financial Accounting Standards, and the provisions of the Financial Services Authority $(O J K)$. Because of the 
use of XBRL, investors can be expected to obtain financial information about the company in real time. This means that the XBRL adoption can reduce the information asymmetry between companies and investors. In particular, the adoption of XBRL will have a positive effect on investor investment decisions with high asymmetric information on the stock market. With the existence of a high level of financial disclosure, it can cause a decrease in information asymmetry in the capital market (Healy, 1992; Leuz, 2000; Welker, 1995), therefore, the research hypothesis in this study is: "The frequency of investor trading ratio is different when pre and post XBRL adoption."

\section{Research Methodology}

This research was conducted on the Indonesia Stock Exchange. By empirically analyzing the effect of XBRL adoption on Investor trading behavior, the type of research conducted was documentation by using panel data (Pooling data).

The population in this study was banking companies listed on the Indonesia Stock Exchange in 2014 (pre XBRL adoption) and 2016 (post XBRL adoption). Out of 81 banking companies listed on BEI, several companies must be taken out because of problems related to the availability, conditions, and completeness of the information needed in the testing so that the final sample became 34 banking companies.

Data collection method used was in the form of archival data or secondary data obtained from the annual financial reports of companies listed on BEI and available at (http://www.idx.co.id).

The study used t-test analysis, by using SPSS-23 program for windows, and conducted testing each variable, i.e., trading frequency, ROA, SIZE, and Dividend Ratio, to find out whether each of these variables changed when before and after the adoption of XBRL. In this study, researchers examined the effect of XBRL adoption on the investors' trading frequency ratio (Young, 2015). Regression equation was formulated as follows:

$$
\text { Turnover_Investorit }=f\left(X B R \text { __Dummy }_{\text {sit }}, \text { Controlit }\right)+\mathbf{e}_{i t}
$$

To calculate the investors' trading frequency ratio as a minimum purchase and sale, that is, the minimum (buy, sell) was divided by the average value of the equity market. Trading frequency ratio increases because investors actively sell their shares relative to the market value of their equity. Thus, a high trading frequency ratio reflects a lot of information about shares traded by investors. XBRL dummy was the main variable and was assigned a value of 1 for before XBRL adoption (for 2014) and a value of 2 for after XBRL adoption (for 2016).

On the other hand, researchers included control variables that can affect the investors' portfolio decisions. To conduct this, the researchers also included the size of the company (Fama, 1992) in the equation. In general, investors in larger companies are more likely to hold shares for a longer period than in small companies because they can easily obtain company information and the volatility of large company stocks is relatively less. Thus, the investor trade turnover ratio will increase because the size of the company becomes larger. We calculate company size as the logarithm of total assets. It is also known that investors tend to invest in the relative blue chip stocks towards investors. Thus, investors will hold value shares with a low market-to-book ratio for a long time. The researchers predicted a positive relationship between ratio and trade turnover of market-to-book ratio from investors.

Investors tend to invest in shares with high profitability and dividend rates as their relative long-term investments to investors. According to Fama, 2011; Jensen, 1992; Li, 2008, the dividend level is positively related to the company's profitability. This is because companies with high profitability can pay more dividends because of the large available profits, dividend payout ratio, asset returns and Z-scores that are negatively related to the investors' trading frequency ratio.

ROA as a proxy for profitability was measured as the ratio of Earnings Before Interest, Taxes, Depreciation, and Amortization (EBITDA) to total assets. The dividend payout ratio was calculated as net income divided by cash dividends. Data were collected through a summary of the financial reports of each banking issuer, which were then analyzed by using ANOVA. 


\section{Result and Discussion}

Based on the table of statistical test results as stated below, it can be illustrated that the statistical decision-making criteria based on the t-table is 2.042 while the t-count is 1.500 , so it can be explained that the t-table $>\mathrm{t}$-count, so it can be concluded that there is no difference of the investors' trading frequency ratio before and after XBRL adoption.

Table 1. Paired Samples Test on Pre XBRL Adoption of Frequency

\begin{tabular}{|c|c|c|c|c|c|c|c|c|c|}
\hline & \multicolumn{5}{|c|}{ Paired Differences } & \multirow[b]{3}{*}{$\mathrm{t}$} & \multirow[b]{3}{*}{ df } & \multirow{3}{*}{$\begin{array}{l}\text { Sig. } \\
(2- \\
\text { tailed } \\
\quad)\end{array}$} \\
\hline & & \multirow[b]{2}{*}{ Mean } & \multirow{2}{*}{$\begin{array}{c}\text { Std. } \\
\text { Deviati } \\
\text { on }\end{array}$} & \multirow{2}{*}{$\begin{array}{l}\text { Std. } \\
\text { Error } \\
\text { Mean }\end{array}$} & \multicolumn{2}{|c|}{$\begin{array}{l}95 \% \text { Confidence } \\
\text { Interval of the } \\
\text { Difference }\end{array}$} & & & \\
\hline & & & & & Lower & Upper & & & \\
\hline $\begin{array}{l}\text { Pair } \\
1\end{array}$ & $\begin{array}{l}\text { Pre XBRL } \\
\text { Adoption } \\
\text { (frequency) - } \\
\text { Post XBRL } \\
\text { Adoption }\end{array}$ & $\begin{array}{r}5.1857 \\
9\end{array}$ & $\begin{array}{r}17.521 \\
58\end{array}$ & $\begin{array}{r}3.0049 \\
3\end{array}$ & -.92777 & $\begin{array}{r}11.2993 \\
6\end{array}$ & $\begin{array}{r}1.72 \\
6\end{array}$ & 33 & .094 \\
\hline
\end{tabular}

Table 2. Paired Samples Test on Pre XBRL Adoption of ROA

\begin{tabular}{|c|c|c|c|c|c|c|c|c|c|}
\hline & \multicolumn{5}{|c|}{ Paired Differences } & \multirow[b]{3}{*}{$\mathrm{t}$} & \multirow[b]{3}{*}{$\mathrm{df}$} & \multirow{3}{*}{$\begin{array}{l}\text { Sig. } \\
(2- \\
\text { tailed })\end{array}$} \\
\hline & & \multirow[b]{2}{*}{ Mean } & \multirow{2}{*}{$\begin{array}{c}\text { Std. } \\
\text { Deviati } \\
\text { on }\end{array}$} & \multirow{2}{*}{$\begin{array}{l}\text { Std. } \\
\text { Error } \\
\text { Mean }\end{array}$} & \multicolumn{2}{|c|}{$\begin{array}{l}95 \% \text { Confidence } \\
\text { Interval of the } \\
\text { Difference }\end{array}$} & & & \\
\hline & & & & & Lower & Upper & & & \\
\hline $\begin{array}{l}\text { Pair } \\
1\end{array}$ & $\begin{array}{l}\text { Pre XBRL } \\
\text { Adoption } \\
\text { (ROA) - Post } \\
\text { XBRL } \\
\text { Adoption }\end{array}$ & $\begin{array}{r}- \\
.11571\end{array}$ & .67154 & .11690 & -.35383 & .12241 & $.990^{-}$ & 32 & .330 \\
\hline
\end{tabular}

Table 3. Paired Samples Test on Pre XBRL Adoption of Size

\begin{tabular}{|c|c|c|c|c|c|c|c|c|}
\hline & \multicolumn{5}{|c|}{ Paired Differences } & \multirow[b]{3}{*}{$\mathrm{t}$} & \multirow[b]{3}{*}{$\mathrm{df}$} & \multirow{3}{*}{$\begin{array}{c}\text { Sig. } \\
(2- \\
\text { tailed) }\end{array}$} \\
\hline & \multirow[b]{2}{*}{ Mean } & \multirow{2}{*}{$\begin{array}{l}\text { Std. } \\
\text { Deviati } \\
\text { on }\end{array}$} & \multirow{2}{*}{$\begin{array}{l}\text { Std. } \\
\text { Error } \\
\text { Mean }\end{array}$} & \multicolumn{2}{|c|}{$\begin{array}{l}95 \% \text { Confidence } \\
\text { Interval of the } \\
\text { Difference } \\
\end{array}$} & & & \\
\hline & & & & Lower & Upper & & & \\
\hline $\begin{array}{cl}\text { Pair } 1 \text { Pre XBRL } \\
\\
\text { Adoption (SIZE) - } \\
\text { Post XBRL } \\
\text { Adoption }\end{array}$ & $\begin{array}{r}.2942 \\
4\end{array}$ & .41523 & .07228 & -.44147 & -.14700 & $\begin{array}{r}4.07 \\
1\end{array}$ & 32 & .000 \\
\hline
\end{tabular}

The following table shows the results of the analysis of variance (ANOVA) which shows the results of different test of the investors' trading frequency ratio before and after XBRL adoption as follows: 
Table 4. Test of differences in mean between pre and post-XBRL periods

\begin{tabular}{|l|r|r|r|}
\hline \multicolumn{1}{|c|}{ Variables } & \multicolumn{1}{c|}{$\begin{array}{c}\text { Post XBRL } \\
\text { Adoption }\end{array}$} & \multicolumn{1}{c|}{$\begin{array}{c}\text { After XBRL } \\
\text { Adoption }\end{array}$} & $\begin{array}{c}\text { Diff.Mean } \\
\text { (t-statistics) }\end{array}$ \\
\hline Frequency & 8.9097 & 3.5615 & 5.3481 \\
\hline ROA & 0.171 & 0.1328 & -1.1571 \\
\hline SIZE & 30.5385 & 30.8327 & -2.9424 \\
\hline DIVIDEND & 2.9227 & 5.8439 & -2.92121 \\
\hline
\end{tabular}

The investors' trading frequency ratio towards XBRL adoption showed a significant level of 0.094 . This showed that there was no difference in pre and post XBRL adoption; this is due to the fact that XBRL was only implemented in the Indonesia Stock Exchange in 2015, so the XBRL trading information had not shown a positive response from investors.

ROA testing of pre and post XBRL adoption showed a significant level, i.e., $>0.330$, and it was greater than the significant level $>0.005$. This indicates that the company's ROA (Return on Investment) has not changed when XBRL adoption was implemented; there has been no positive response from investors.

SIZE testing of pre and post XBRL adoption showed a significant level, i.e., 0.000 , this indicates that the size was affected by the XBRL response, this means that small companies respond from the existence of XBRL, this is that small investors respond to XBRL. This response occurs because of the additional convenience obtained to get information that is more transparent and relevant to the expected investment decision making. That as XBRL enables small investors to easily obtain a company's financial information and consequently mitigates asymmetry. Furthermore, the associated information was incorporated into trading behavior of some investors and, as a result, their trading turnover ratio has increased (Choi; 2015).

The DIVIDEND testing of pre and post XBRL adoption showed a significant level of 0.005 , this indicates that dividend affected the XBRL response. With the investors' responding to XBRL, the possibility of investors to increase their trading frequency affected the possibility of obtaining greater dividends. According Zhao (2008), the dividend level is positively related to a firm's profitability. This is because firms with high profitability can pay more dividends due to their large available earnings.

\section{Conclusion}

Based on the statistical test results and discussions, it can be concluded that there were no differences in the effect before or after XBRL adoption towards the share investors' trading frequency ratio in the Indonesia Stock Exchange. For the next researches, it is recommended to use data from issuers categorized as LQ45.

\section{References}

Choe, H., Kho, B-C. Stulz, RM. (1999). Do foreign investors destabilize stock markets? The Korean experience in 1997. J Finance Econ, 54(2): 227-64.

Choi, Y. M. (2015). The effect of XBRL adoption on trading behaviors of foreign investors: Evidence from Korea. Indian Journal of Science and Technology, 8(21).

Chuhan, P. (1994). Are institutional investors an important source of portfolio investment in emerging markets? World Bank working paper.

Debreceny, R., Farewell, S., Piechocki, M., Felden, C., Graning, A. \& D’Eri, A. (2011). Flex or break? Extensions in XBRL disclosure to the SEC. Accounting Horizon, 25(4): 631-57. 
Efendi, J., Park, J. \& Smith, M. (2014). Do XBRL filings enhance informational efficiency? Early evidence from post-earnings announcement drift. J Bus Res., 67(6): 1099-105.

Fama EF, French KR. (1992). The cross-section of expected stock returns. J Finance, 47(2): 427-65. (2001). Disappearing dividends: changing firm characteristics or lower propensity to pay? J Finance Econ, 60(1): 3-44.

Hagerman, R. \& Healy, J. (1992). The impact of SEC-required disclosure and insider-trading regulations on the bid-ask spreads in the over-the-counter market. Journal of Accounting and Public Policy, 11(3): 233-43.

Hodge, F., Kennedy, M. and Maines, L. (2014). Does search-facilitating technology improve transparency offinancial reporting?, Accounting Review, 79(3): 687-703.

Jensen, GR., Solberg, DP. \& Zorn, TS. (1992). Simultaneous determination of insider ownership, debt, and dividend policies. Journal of Financial and Quantitative Analysis. 27(2): 247-63.

Kang, J-K. \& Stulz, RM. (1997). Why is there a home bias? An analysis of foreign portfolio equity ownership in Japan. J Financ Econ, 46(1): 2-28.

Leuz, C. \& Verrecchia, R. (2000). The economic consequences of increased disclosure. $J$ Account Res, 38: 91-124.

Li K, Zhao X. (2008). Asymmetric information and dividend policy. Finance Management, 37(4): 673-94.

Oswari, T \& Januarianto, A. (n.d). Extensible Business Report Language (XBRL) Implementation of Financial Reporting Standard in Indonesian Banking Industry.

Welker, M. (1995). Disclosure policy, information asymmetry and liquidity in equity markets. Contemporary Accounting Research, 11(2): 801-27.

White, H. (1980). A heteroskedasticity-consistent covariance matrix estimator and a direct test for heteroskedasticity. Econometrica, 48(4): 817-38.

Yong Mok Choi. (n.d). The Effect of XBRL Adoption on Trading Behaviors of Foreign Investors: Evidence From Korea.

Yoon H, Zo H, Ciganek A. (2011). Does XBRL adoption reduce information asymmetry? J Bus Res, 64(2): 157-63. 